\title{
БіопсихічнА ПіАСтрУктурА
}

Maksymenko S. D. Biopsychic substructure / S. D. Maksymenko // Problems of Modern Psychology : Collection of research papers of Kamianets-Podilskyi National Ivan Ohiienko University, G. S. Kostiuk Institute of Psychology of the National Academy of Educational Sciences of Ukraine / scientific editing by S. D. Maksymenko, L. A. Onufriieva. - Issue 41. - Kamianets-Podilskyi : Aksioma, 2018. - P. 7-15.

S. D. Maksymenko. Biopsychic substructure. It is stated in the article that the integrity of the ontogenesis of the psyche should be considered in another plane, i.e. as the integrity of the human way of life from birth to death. It is noted that at the same time it should not be abstracted from the anatomical-morphological structures. After all, the specificity of human ontogenetic development lies in the fact that it obeys both the actions of biological laws (as well as the development of animals), and the actions of social and historical laws. It is shown that the correlation between biological and mental in the personality always changes its configuration, changes its meaning: one thing when it comes to this relationship at very deep levels, the existence of root leaning, the needs of organizm, and completely different - the combination of biological and mental, for example, in activities. In some studies, it is shown that the correlation between biological and mental changes in the personality in the process of ontogenesis. It is noted that the biological and mental principles function in man together: these are two processes that coexist, work on each other. They are relatively independent and they unite, and create, in fact, the so called personality. It is found that considering the biopsychic substructure, we should not forget our initial logic of personality's ontogenesis. It is stated that we understand the emergence of personality as a holistic carrier of the human psyche, as a result of a combination of life, a very long association of biological processes and social processes. It is shown that the psyche itself is the resultant force, the resultant vector of the union of these two wings, and in this sense, if we keep in mind our notions of ontogenesis and need as an energetic and informative force, the concept of biopsychic in general should be removed, because all biological in the personality is human; it is not purely biological, it is also social at the same time. It is concluded that, on the other hand, all that we know about the personality, of course, is social: the relationship, human activities, relations, ideas. All this exists due to the fact that there is body as a whole above the brain. Therefore, this structure is represented as initial, root, and psychic.

Key words: personality, human activities, relations, biopsychic substructure, biological processes, social processes, leaning, correlation, ontogenesis, need, biopsychic, mental processes. 
С. Д. Максименко. Біопсихічна підструктура. У статті констатовано, що цілісність онтогенезу психіки слід розглядати і в іншій площині - як цілісність життєвого шляху людини від народження до смерті. Зазначено, що при цьому зовсім не слід абстрагуватись від анатомо-морфологічних структур (задатків). Адже специфіка онтогенетичного розвитку людини полягає в тому, що він підпорядковується і дії біологічних законів (як розвиток тварин), і дії суспільно-історичних законів. Показано, що співвідношення біологічного і психічного в особистості завжди змінює свою конфігурацію і зміст: одна справа, коли йдеться про це співвідношення на дуже глибинних рівнях, в існуванні кореневих потягів, організмічних потреб, і зовсім інша - коли береться поєднання біологічного і психічного, наприклад, у діяльності. У деяких дослідженнях показано, що співвідношення біологічного і психічного змінюється в особистості у процесі онтогенезу. Зазначено, що біологічне і психічне в людині функціонують разом: це два процеси, які співіснують і працюють один на одного. Вони відносно незалежні i, конверзуючись, об'єднуючись, створюють, власне, те, що називається особистістю. 3'ясовано, що розглядаючи біопсихічну підструктуру, слід не забувати нашу вихідну логіку щодо онтогенезу особистості. Констатовано, що ми розуміємо появу особистості як цілісного носія психіки людини, як результат поєднання довічного, дуже давнього об'єднання біологічних процесів і процесів соціальних. Показано, що сама психіка є результуючою силою, результуючим вектором об'єднання цих двох крил, і в такому розумінні, якщо мати на увазі наші уявлення про онтогенез і про нужду як енергетично-інформаційну силу, завдяки якій існує все живе на Землі, поняття біопсихічного взагалі-то повинно бути знято, тому що все біологічне в особистості є олюдненим, воно не є чисто біологічним, воно водночас є і соціальним. Підсумовано, що, з іншого боку, все, що ми знаємо про особистість, безумовно, є соціальним: це взаємовідносини, діяльність людини, її стосунки й ідеї. Усе це є завдяки тому, що існує не мозок, а тіло як ціле. Тому ця структура уявляється як вихідна, коренева, психічна.

Ключові слова: особистість, діяльність людини, стосунки, біопсихічна підструктура, біологічні процеси, соціальні процеси, потяг, співвідношення, онтогенез, нужда, біопсихічне, психічні процеси.

Постановка проблеми. Сучасна практична психологія являє собою досить строкату i, водночас, сумну картину. Безліч емпіричних даних (які дуже часто невідомо про що говорять), саморобних, житейських за своєю суттю, теоретичних схем, що зазвичай відображають лише одне - особливості розумового процесу своїх авторів, а десь зовсім осторонь - фундаментальні філософсько-методологічні положення про буття і свідомість, активність, сутність і явище тощо. 
Важливим мотивом нашої підвищеної уваги до методологічних підвалин генези психіки є бажання якось зрушити з місця низку проблем психологічної практики. Відсутність дійсної теоретичної основи призводить до того, що, скажімо, така необхідна і важлива робота в галузі психології розвитку дитини або просто відсутня, або грунтується на суто житейських уявленнях практичного психолога.

Наші дані також свідчать про те, що цілісність онтогенезу психіки слід розглядати і в іншій площині - як цілісність життєвого шляху людини від народження до смерті. При цьому зовсім не слід абстрагуватись від анатомо-морфологічних структур (задатків), про що наша психологія сором'язливо мовчала багато років. Адже специфіка онтогенетичного розвитку людини полягає в тому, що він підпорядковується і дії біологічних законів (як розвиток тварин), і дії суспільно-історичних законів.

Аналіз досліджень і публікацій. Свого часу К. Г. Юнг досить яскраво говорив про те, що нам просто не під силу дійсно зрозуміти й висловити єдність біологічного і психічного в існуванні людини. Він вважав, що це питання не психологічне, а філософське, отже, на рівні позитивної науки його просто слід прийняти і з ним працювати. У цій роботі вже доволі багато говорилось про проблему взаємодії біологічного і соціального, але в дійсності важливіше виокремити дещо інший аспект - тенденцію, функціонально-динамічне явище співіснування біологічного і психічного.

Традиційно психічне розуміється як сукупність психічних явищ, відомих усім. Біологічне ж е тим, що стосується життя організму, життя тіла, його функцій, структури. Але ми не маємо насправді окремого існування того й іншого, просто вони порізному між собою з'єднуються на різних етапах онтогенезу.

Співвідношення біологічного і психічного в особистості завжди змінює свою конфігурацію і зміст: одна справа, коли йдеться про це співвідношення на дуже глибинних рівнях, в існуванні кореневих потягів, організмічних потреб, і зовсім інша - коли береться поєднання біологічного і психічного, наприклад, у діяльності. Вони й тут, безумовно, поєднані, але поєднані по-іншому. Якщо на глибинному рівні це є біопсихічна напружена єдність, частини якої не можуть існувати одна без одної, то на рівні більш поверхневому ми можемо говорити про іншу природу взаємодії.

У деяких дослідженнях показано, що співвідношення біологічного і психічного змінюється в особистості у процесі онтоге- 
незу. Вже зазначалося, що О. Р. Лурія [3] показав, що воно не є незмінним. Точка зору О. Р. Лурії дуже мало, на жаль, використовується в сучасній психології. Традиційно вважається, що на більш ранніх етапах онтогенезу в дитини переважає в діяльності й активності біологічний компонент, а на пізніших етапах переважаючими стають соціальні чинники. О. Р. Лурія, який проводив дослідження мислення та пам'яті дітей і дорослих, показав протилежну картину, причому вона доведена емпіричними фактами i, в принципі, не викликає жодних сумнівів.

На початкових етапах онтогенезу процеси мислення і пам'яті якраз найбільш соціалізовані, вони максимально залежать від умов виховання і тієї діяльності, у якій дитину, власне, вчать мислити і запам'ятовувати. Ці процеси лише поступово починають набувати індивідуально-неповторної природи, і в ній виявляються власне спадкові й генетичні чинники. Якщо слідувати логіці Лурії, індивідуальне виникає від того, що біологічне, спадкове займає все більше місця в діяльності того чи іншого процесу.

Здається, що це можна поширити на всі процеси, хоча це буде лише припущення, тому що інших емпіричних досліджень у цьому напрямі не проводилось. Незрозумілим залишається, чому на перших етапах онтогенезу біологічне, спадкове ніби придушується соціальним досвідом, який активно захоплює людину, і як воно вивільняється в подальшому, як соціальне вступає в нові взаємостосунки з біологічним. Ці механізми, процеси i явища вимагають емпіричних досліджень, але нам здається, що в контексті означеної проблеми потрібно звертати на це увагу.

Мета нашої роботи - здійснити теоретико-методологічний аналіз взаємодії біологічного і психічного у межах підструктури особистості.

Виклад основного матеріалу дослідження. Особливості взаємодії біологічного і психічного у межах підструктури особистості полягають у тому, що її «відголоски», наслідки відображаються в цілісній особистості взагалі, і будь-яке явище, будь-яка особливість містить у собі це співвідношення як виявлення їхньої єдності. Конкретним проявом є, наприклад, явище психосоматики, яке привертає в наш час найбільшу увагу практиків. Ti, хто займається прикладними дослідженнями, практичною психологією, медичною психологією, відкривають дуже багато невідомих поки що механізмів співвідношення розвитку особистості загалом. Медицині зараз відомі факти, що до 80\% виразок шлунку мають психогенну природу, а також багато інших фактів. 
Але знову-таки ми не знаємо механізмів: що психічно впливає на роботу соматичних органів, і можна навести багато фактів, коли існує і зворотний вплив: стан соматичний, стан системи органів впливає на психологічне функціонування особистості загалом. Зрозуміло, що подібні речі є серйозним підтвердженням дійсної єдності людської істоти. Але, з іншого боку, вони вимагають проведення науково-психологічних досліджень. Адже, крім статистики і суто житейських спостережень, не існує на даний момент інших знань про дійсні механізми подібних явищ.

Слід згадати точку зору Виготського, який ставив перед психологією задачу: не теоретизувати на рівні цих життєвих фактів, які є очевидними, а отримувати наукові факти і вже від них відштовхуватися для пізнання дійсної психології явища. Тож неможливо в цій роботі давати якісь змістовні характеристики психосоматики, через те що це явище вимагає серйозних емпіричних досліджень, яких практично немає, як і в медичній психології. Зокрема, в розділі, присвяченому онтогенезу, ми говоримо про любов і зазначаємо, що галузь психосоматики не досліджує, як психічні стани і психічні особливості батьків впливають на продукування статевих клітин i, отже, на подальше зростання i розвиток дитини, яка розвивається. Але це означає не те, що цього впливу немає, а те, що дослідження в цьому напрямі не ведуться. Навіть на поверхневому, статистичному рівні ми таких досліджень не маємо, хоча їх не так важко здійснити.

У межах аналізу цієї підструктури викликає увагу дуже цікава теорія провідних тенденцій Л. М. Собчик [4]. Вона виокремлює в особистості темпераментальні властивості, які у найчистішому вигляді втілюють дійсне поєднання біологічного і психічного. Кожна властивість темпераменту і є ніби «зернятком»: у ній дуже чітко видно, «що там із біології і що з психології». Л. М. Собчик підкреслює, що це є не властивості, а тенденції, тобто вони мають енергетично-динамічну природу, розвиваються i, розвиваючись, орієнтуються і формують стабільні якості особистості в галузі поведінки.

Автор продовжує цю логіку до характерологічних рис, до комунікації та спілкування особистості в соціумі, показуючи, що прояв тенденцій, їх угруповання забезпечує зовсім різні поведінкові стилі. Темперамент як зернятко, як клітинку біологічного i психічного розглядає не лише Л. М. Собчик. Це, можливо, найбільш давні й традиційні дослідження. У вітчизняній психофізіології можна назвати Б. М. Теплова, Небиліцина і їхню школу. 
Це і теорії темпераменту Кречмера і Шелдона, які, щоправда, розглядали єдність на конституціональному рівні, й дуже багато робіт у галузі фізіології мозку, що мають «вихід» саме в динаміку, тобто в темперамент.

Ми згадали Л. М. Собчик, тому що вона робить, на наш погляд, крок уперед, говорячи про тенденції, про те, що вони пронизують далі всю особистість і їі вершинні рівні, такі як цінності, спрямованість, характер, досвід. Тенденції зумовлюють індивідуальний стиль діяльності та поведінки. Отже, на даний момент існує достатній емпіричний матеріал у традиційній психології, щоб говорити про наявність певної теорії біопсихічної єдності людини.

Дещо окремо у межах цієї підструктури існує проблема тілесності. Традиційно в сучасній психології, аналізуючи біологічне і психічне в особистості, говорять про нервову систему, за винятком, можливо, зазначених вище імен: Кречмера і Шелдона, які аналізують тілесне. I нам уявляється, що роботи, наприклад, фрейдиста Райха, Кречмера, О. М. Сікорського в галузі фізіогноміки та філософські обгрунтування, яким присвятив увагу О. Ф. Лосєв і багато інших учених, повинні повернутися в психологію, оскільки особистість являє собою далеко не лише набір нематеріальних за природою психічних структур.

Ми говоримо про особистість, маючи на увазі обов'язково цілісну людину, а людина без тіла не існує взагалі: без обличчя, без тілесної структури. I мова йде не лише про вплив особливостей тіла на особистість чи психіку, йдеться про єдність. В останніх дослідженнях О. Т. Соколової [5] яскраво показано, що образ тілесного Я, образ тіла і саме тіло є дуже важливими психологічними компонентами і водночас причиною численних відхилень у поведінці підлітків і дорослих людей, розвитку різноманітних комплексів.

Тобто, психологія поступово повертається до того, щоб розглядати тіло не як носія психіки, носія ідеального, а як складовий компонент, просто необхідну складову особистості загалом. Справа в тому, що логіка нам підказує: все тілесне в людині - це є водночас і психічне. Звісно, тут потрібно зазначити, що найважливішою є теоретична конструкція М. О. Бернштейна [1]: його «психологія живого руху» засвідчила цю дійсно реальну єдність тілесного і психічного: це є дві назви одного і того ж самого. Будь-який рух, найелементарніший, найпримітивніший прояв 
артикуляції чи руху в просторі - це обов' язково явище психічне настільки ж, наскільки і фізичне. Тому будова тіла, особливості тіла дуже рано входять у тезаурус особистості. Дитина дуже рано знайомиться зі своїм тілом, її образ «Я», самосвідомість абсолютно не відокремлені від тіла. Тобто, все тілесне є психічне.

I тут ми згодні з А. Маслоу в тому плані, що у людини немає виключно і чисто натурального тіла як такого. Тіло визначає образ «Я» так само, як його визначає дух. Тобто, тілесність є структурним компонентом особистості i, як така, обов'язково повинна входити до психології особистості, адже ми не можемо уявити особистість як «голову професора Доуеля». Про це свого часу говорив О. М. Леонтьєв, який, між іншим, не відносився до вчених фізіологічного напряму. Він належав до того напряму психології i філософії у вітчизняній науці, що був, з одного боку, наляканий політизованим тиском павловського вчення, а з іншого - сам був агресивно налаштований проти цього, i тому його звинуватити у фізіологізмі ніяк не можна. Але і його роздуми про фізіологічне і біологічне, фізіологічне і психічне показують, що це є відпочаткова єдність [2].

Правильно зазначає Е. В. Ільєнков, що ми не можемо шукати в будові й у фізіології мозку психічний процес, оскільки це повертає до ідеї «гомункулуса», якого ми там, звісно, не знайдемо, але це крайня і полемічно загострена точка зору. Вже давно у фізіології нервової системи та у фізіології загалом не вживають такі терміни, ніби дійсно потрібно шукати якийсь таємничий процес або субстанцію психічного.

Це, повторимо, крайня точка зору. Мова йде зовсім про інше: говорячи про особистість, ми не можемо відокремити її від її тіла, так як відокремив фантаст Бєляєв голову професора Доуеля. Це означає, що все тілесне пронизане психікою, розумом людини, який є символікою, а, отже, він проходить через всю свідомість. На це хотілося б звернути увагу.

I, нарешті, аналізуючи біопсихічну підструктуру, ми не повинні обійти традиційну, давню думку В. Штерна [6] про конвергенцію. Учений дуже багато зробив для психології особистості, це найвидатніший персонолог, саме він, взагалі-то, і започаткував персонологію як науку. Розглядаючи центральну проблему біологічного і психологічного та їх співвідношення, що представлялась традиційно як протистояння, Штерн уперше висунув ідею конвергенції, тобто поєднання. 
Мається на увазі, що біологічне і психічне в людині функціонують разом: це два процеси, які співіснують і працюють один на одного. Вони відносно незалежні i, конверзуючись, об’єднуючись, створюють, власне, те, що називається особистістю. 3 цією точкою зору можна погодитися, якщо не зважати на нашу вихідну ідею про те, що насправді психологічне в особистості є вектором, який виникає на поєднанні біологічного і соціального. I на цьому ми хотіли б тут акцентувати.

Висновки. Розглядаючи біопсихічну підструктуру, слід не забувати нашу вихідну логіку щодо онтогенезу особистості. Ми розуміємо появу особистості як цілісного носія психіки людини, як результат поєднання довічного, дуже давнього об'єднання біологічних процесів і процесів соціальних.

Сама психіка є, на наш погляд, результуючою силою, результуючим вектором об'єднання цих двох крил, і в такому розумінні, якщо мати на увазі наші уявлення про онтогенез і про нужду як енергетично-інформаційну силу, завдяки якій існує все живе на Землі, поняття біопсихічного взагалі-то повинно бути знято, тому що все біологічне в особистості є олюдненим, воно не є чисто біологічним, воно є водночас і соціальним.

З іншого боку, все, що ми знаємо про особистість, безумовно, є соціальним: це взаємовідносини, діяльність людини, її стосунки й ідеї. Усе це є завдяки тому, що існує не мозок, а тіло як ціле. Тому ми цю структуру уявляємо як вихідну, кореневу, психічну .

\section{Список використаних джерел}

1. Бернштейн Н. А. Очерки по физиологии движений и физиологии активности / Н. А. Бернштейн. - М. : Медицина, 1966. -349 с.

2. Леонтьев А. Н. Деятельность. Сознание. Личность / А. Н. Леонтьев // Избр. псих. труды : В 2 т. - Т. 2. - М. : Педагогика, 1983. - С. 94-231.

3. Лурия А. Р. Об историческом развитии познавательных процессов / А. Р. Лурия. - М. : Наука, 1974. - 171 с.

4. Собчик Л. М. Введение в психологию индивидуальности / Л. М. Собчик. - Москва, 2000. - 506 с.

5. Соколова Е. Т. Самосознание и самооценка при аномалиях личности / Е. Т. Соколова. - М. : МГУ, 1989. - 214 с.

6. Штерн В. Персоналистическая психология / В. Штерн // История зарубежной психологии. - М. : Изд-во Моск. ун-та, 1986. - C. 186-200. 


\section{Spysok vykorystanyh dzherel}

1. Bernshtejn N. A. Ocherki po fiziologii dvizhenij i fiziologii aktivnosti / N. A. Bernshtejn. - M. : Medicina, 1966. - 349 s.

2. Leont'ev A. N. Dejatel'nost'. Soznanie. Lichnost' / A. N. Leont'ev // Izbr. psih. trudy : V 2 t. - T. 2. - M. : Pedagogika, 1983.S. 94-231.

3. Lurija A. R. Ob istoricheskom razvitii poznavatel'nyh processov / A. R. Lurija. - M. : Nauka, 1974. - $171 \mathrm{~s}$.

4. Sobchik L. M. Vvedenie v psihologiju individual'nosti / L. M. Sobchik. - Moskva, 2000. - 506 s.

5. Sokolova E. T. Samosoznanie i samoocenka pri anomalijah lichnosti / E. T. Sokolova. - M. : MGU, 1989. - 214 s.

6. Shtern V. Personalisticheskaja psihologija / V. Shtern // Istorija zarubezhnoj psihologii. - M. : Izd-vo Mosk. un-ta, 1986. S. $186-200$.

Received February 20, 2018

Revised March 16, 2018

Accepted April 13, 2018

\section{УДК 159.947.24}

DOI10.32626/2227-6246.2018-41.15-40

Ю. А. Алєксєєва

yulya-alekseeva-74@ukr.net

\section{КогнітивнА ПрирОАА віри}

Alieksieieva Y. A. The cognitive nature of faith / Y. A. Alieksieieva // Problems of Modern Psychology : Collection of research papers of Kamianets-Podilskyi National Ivan Ohiienko University, G. S. Kostiuk Institute of Psychology of the National Academy of Educational Sciences of Ukraine / scientific editing by S. D. Maksymenko, L. A. Onufriieva. - Issue 41. - Kamianets-Podilskyi : Aksioma, 2018. - P. 15-40.

Y. A. Alieksieieva. The cognitive nature of faith. The article presents the conceptual views on the cognitive aspects of the nature of faith. The faith is considered as a cognitive phenomenon from the standpoint of philosophical generalizations. The relationship of faith, cognitive processes and components of the personality is analyzed on the basis of the existing psychological concepts that enabled to develop the idea of a systematic organization of the cognitive-personal activities, where faith fulfills the function of the main system-based element. The development of belief from the hypotheses to the knowledge that is formed in the social and individual consciousness is presented. This way can be represented in the form of a 